\title{
The life of wood in North-eastern Europe in AD $1100-1600$
}

\author{
Visa Immonen ${ }^{1,{ }^{*}}$, Janne Harjula ${ }^{1}$, Mia Lempiäinen-Avci ${ }^{1}$, Ilkka Leskelä ${ }^{1}$, \\ Elina Räsänen ${ }^{1} \&$ Katri Vuola ${ }^{1}$ \\ ${ }^{1}$ Department of Archaeology, University of Turku, Finland \\ * Author for correspondence: vialim@utu.fi
}

This project develops theoretical as well as methodological tools for the study of ancient wood, focusing on wood-use in North-eastern Europe within the period AD 1100-1600. The authors approach wood within the framework of object biographies and link the study of wooden artefacts with broader archaeological understandings of formation processes and environmental reconstruction.

Keywords: North-eastern Europe, medieval, wood, materiality, object biography

\section{Introduction}

The global crisis of diminishing forest cover has made historical wood-use particularly topical. For premodern communities living in the subarctic region, wood was ubiquitous, and its analysis provides insights into their dependence on woodlands. Despite its omnipresence, research on ancient wood currently falls across several disciplines. To overcome these disciplinary divisions, our project, 'Carving out Transformations: Wood Use in North-Eastern Europe, 1100-1600', brings together scholars from different disciplines to develop theoretical as well as methodological tools for the study of ancient wood. Here, we describe our approach to wood within a framework of object biography, and connect wooden objects to archaeological concepts of formation processes and environmental reconstruction.

Our core question is how wood and wooden objects moved around and were transformed in North-eastern Europe during the Middle Ages, and how these movements were entangled with lifeways and interactions between humans, animals, the environment and the divine. North-eastern Europe constitutes a particularly interesting case study for the pre-modern use of wood. There, urbanism reached its northernmost point, and the vast forest wilderness began. It was also a frontier region, where settled agricultural communities and those practising hunting and gathering, herding, and slash-and-burn agriculture interacted.

\section{The materiality of multiple objects}

Our project engages with contemporary debates on materiality, a concept encompassing both physical entities and cultural processes. Despite extensive discussions on materiality in the humanities, the dialogue with material sciences has, to date, been less rigorous. To find points

Received: 8 January 2020; Revised: 24 March 2020; Accepted: 8 April 2020

(C) The Author(s), 2020. Published by Cambridge University Press on behalf of Antiquity Publications Ltd 
of access across disciplines, our project employs the conceptual methodology of 'object biography'. Emerging in the 1980s, the methodology has since been critiqued and transformed, with the introduction of such alternative concepts as 'itinerary' (Joyce \& Gillespie 2015), and 'multiple objects' (Jones et al. 2016). Understanding these conceptual changes is vital for approaching wood as a material, medium and agent of transformation.

Our approach to wood requires a multi-dimensional research strategy incorporating the material, social and cultural study of objects. The methodology can be characterised as 'following the material' (Weismantel \& Meskell 2014). Starting from the material substances, and the locations in which they were changed, circulated and deposited, the analysis concentrates on the presence of wood in different locations, and the representations of which it was part.

\section{Formation processes}

The acidic soils of North-eastern Europe do not favour the survival of ancient wood, but there are certain environments in which it can endure in pristine condition; these include anaerobic urban cultural layers that preserve wooden objects, architectural features and tools of woodworking (Morris 2000; Gläser 2006). While the most famous of such places is Novgorod with its mass of organic finds (Brisbane \& Hather 2007), other towns, such as Turku, have also revealed large assemblages of similar objects (Figures 1-2). Bogs distributed widely across the subarctic wilderness also provide waterlogged conditions in which ancient wood can survive (Taavitsainen $e t$ al. 2007). Although wooden bog finds are typically individual stray objects,

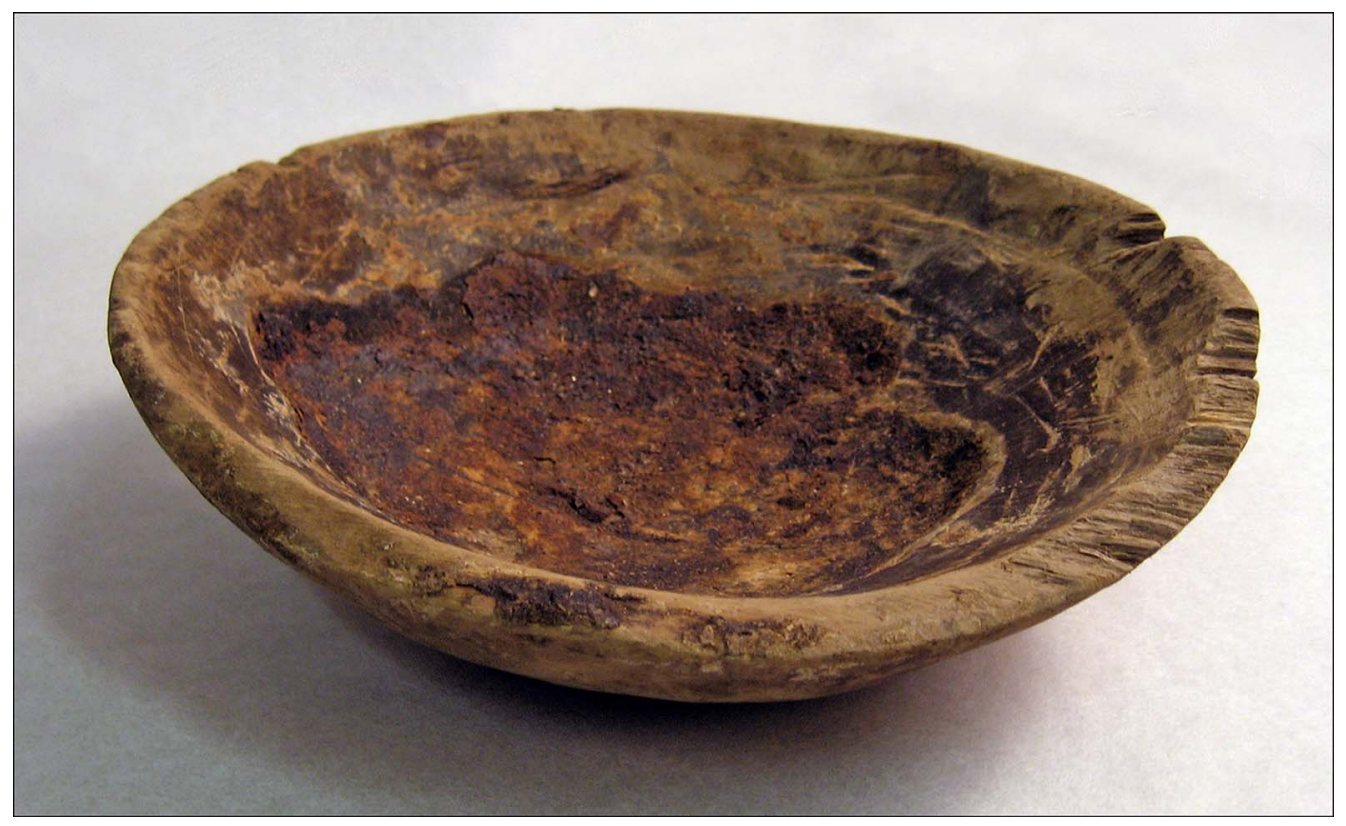

Figure 1. Late fourteenth-century wooden bowl, possibly made from a deciduous tree, found in the town of Turku (photograph by J. Harjula).

(C) The Author(s), 2020. Published by Cambridge University Press on behalf of Antiquity Publications Ltd 


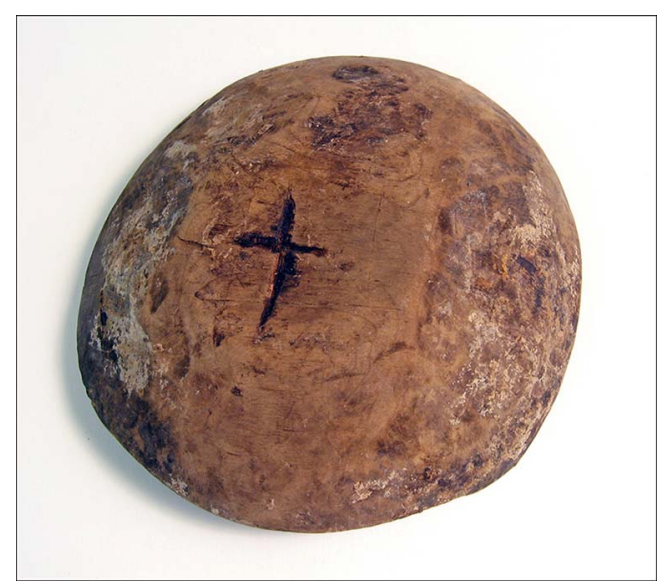

Figure 2. Underside of the wooden bowl (Figure 1), with an apotropaic cross on the base, found in the town of Turku (photograph by J. Harjula). their wide geographic distribution gives them particular importance. In addition, Northern European churches house hundreds of medieval wooden sculptures (Kroesen \& Schmidt 2009) that have not been viewed as archaeological objects in the conventional sense. We have chosen these three very different material groups as the basis for analysing the varied use of wood in the Middle Ages, but we also utilise environmental data to build a broader context for medieval wood-use. This balances the study of objects with the analysis of the impact of humans on northern forests (e.g. Reilly 2012; Bunting \& Farrell 2018).

\section{Phases of wooden life}

There are four essential phases in the life cycle of wood in medieval society, each with specific research questions. The first is the acquisition of wood. In reconstructing this phase, understanding palaeoenvironmental circumstances is crucial for determining the quality and availability of trees (Alenius et al. 2010). The project also aims to determine the resulting impact of the consumption of wood, for manufacturing objects and for fuel and construction, on the premodern landscape.

In addition to dating objects, the identification of tree species is a rudimentary procedure (Vuola 2019). Botanists usually conduct species identification by analysing the cellular structure of wood, but the project also assesses the potential application of proteomics or zooarchaeology by mass spectrometry (ZooMS). ZooMS is based on determining sequence differences in peptides, which allows us to distinguish between species. Plants also produce identifiable peptides that could be recognised by the ZooMS technique. This depends on ZooMS adequately processing wood samples, which is not yet fully reliable, but which shows much promise.

After acquisition, the wood was prepared for use. Techniques used for transforming wood include turning, carving, bentwood, jointing and cooperage. Toolmarks, production waste and the surviving woodworking tools can all help to reconstruct production techniques. This raises questions about the scale of production and its requirements: does it represent casual domestic activity or a commercial workshop? This in turn dictates the impact on local resources.

Baxandall (1980) highlights the importance of the materiality of wood for medieval ecclesiastical sculptures, emphasising their 'woodness'. Conversely, many wooden objects were designed to hide their raw material under rich polychrome, textiles and other adornments (Taubert 2015). Analysing whether such a duality between presence and representation is relevant for the study of wooden objects requires sensitivity to the materials. 


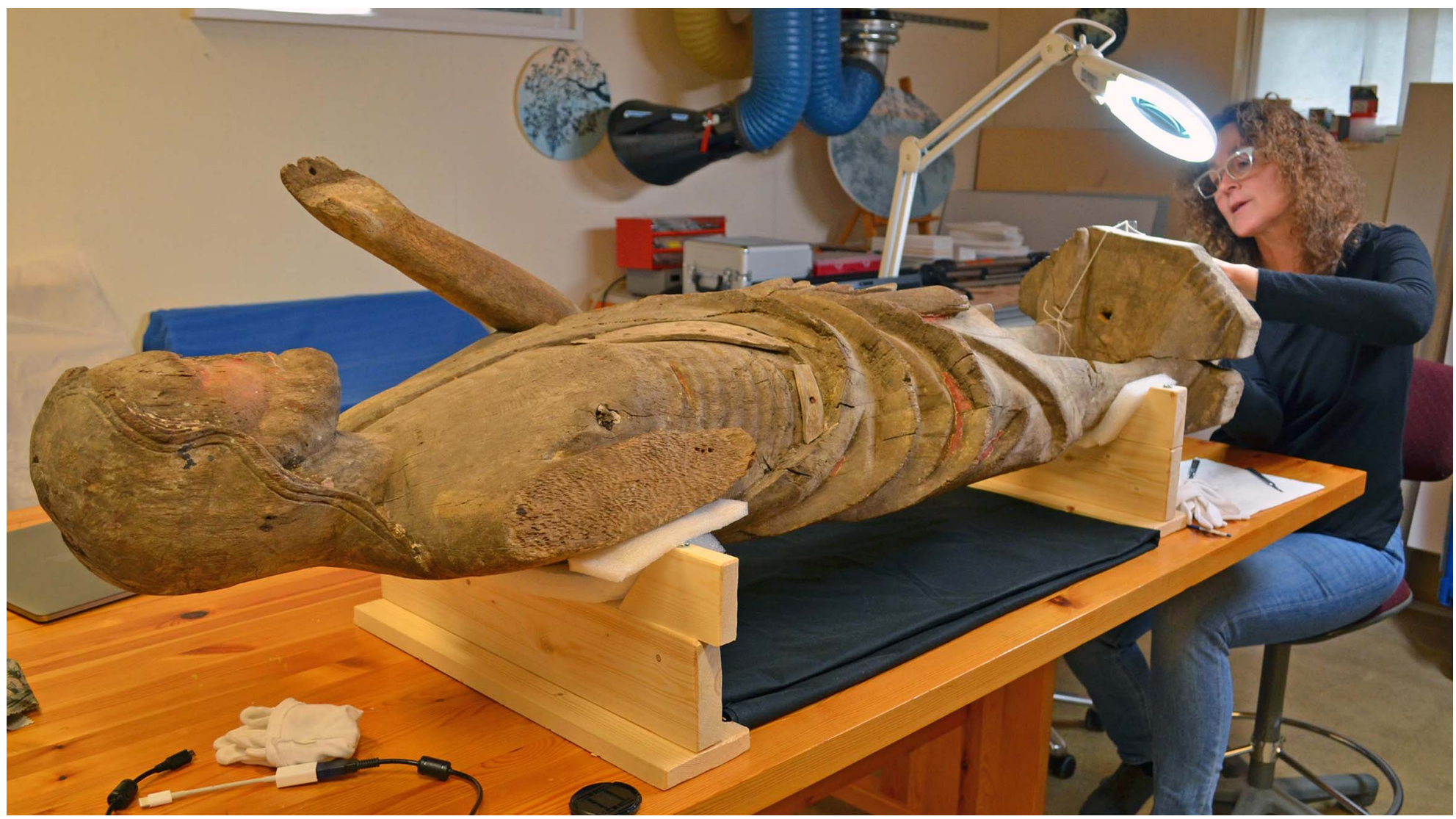

Figure 3. Fourteenth-century sculpture of the Resurrected Christ from the Church of Karjaa, prepared for dendrochronological analysis by conservator Jaana Paulus (photograph by K. Vuola). 
The third phase of wood-use is the distribution and sale of finished products. The traditional focus of archaeological, art-historical and historical research has been the provenance of products; the networks of trade through which they moved; which products were produced and sold locally; which were regionally traded; and which were part of interregional commerce. This project, however, also considers the more emotive aspect of wooden objects by tracing their biographies through written evidence. We will examine fifteenth- and sixteenth-century examples of wood being specifically documented and commented on in writing. This will form the basis for a comparison between the views expressed in the writing and the archaeological evidence for wood resources and management.

The fourth and final phase in the lives of wooden objects, their use, is the most difficult to access. In reconstructing use, acknowledging the heterogeneity of wood is pivotal. In churches, wooden objects evoked the divine, forming part of a deliberate visual vocabulary in sacred space (Figure 3). Wood communicated the divine through material representation of the ethereal. Wooden sculptures act as agents with the capacity to influence the beholder's perception and induce a desire to commune with God-yet they are carved and crafted by human hands. In the words of Binski (2019: 3-4), "the human 'poetics' of materials matter because they lend rationally guided eloquence to things: materials and style together possess intent". Wooden objects were not immutable and could be reworked, making possible the alteration of sculptures; the identities of holy figures could be altered during their active liturgical use (Tångeberg 2005) and were, particularly after the Reformation.

\section{Following the material}

The project's aim is to produce individual case studies on each of the three object categories: objects from the bog, the church and the urban context; but it will also seek to find connections between the groups. We will consider whether similar wood species were chosen for each category, or if there were associations between species and use. We will investigate the similarity of production techniques between the different groups. In addition to these practical and technical concerns, we will produce environmental reconstructions related to forests and the impact of wood-use. Ultimately, the project aims to understand the role of wood in socio-cultural, ecological and theological networks, and in particular to recognise the multiple connections between these.

\section{Funding statement}

This research received funding from the Academy of Finland (decision 315540).

\section{References}

Alenius, T., M. SaArnisto, J.-P. Taavitsainen \& J.-P. LunKKa. 2010. Pollen record of land use and medieval settlement history in Vuonninen, northern Russian Karelia. Geoarchaeology 26: 1-22. https://doi.org/10.1002/gea.20340
BaXANDALL, M. 1980. The limewood sculptors of Renaissance Germany. New Haven (CT): Yale University Press.

Binski, P. 2019. Gothic sculpture. New Haven (CT): Yale University Press. 
Brisbane, M. \& J. Hather. (ed.). 2007. Wood use in medieval Novgorod. Oxford: Oxbow.

Bunting, M.J. \& M. Farrell. 2018. Seeing the wood for the trees: recent advances in the reconstruction of woodland in archaeological landscapes using pollen data. Environmental Archaeology 23: 228-39. https://doi.org/10.1080/14614103.2017. 1377405

GLÄSER, M. (ed.). 2006. Lübecker Kolloquium zur Stadtarcäologie im Hanseraum V: das Handwerk. Lübeck: Schmidt-Römhild.

Jones, A.M., M. Díaz-Guardamino \&

R.J. Crellin. 2016. From artefact biographies to 'multiple objects': a new analysis of the decorated plaques of the Irish Sea region. Norwegian Archaeological Review 49: 113-33. https://doi.org/10.1080/00293652.2016.1227359

Joyce, R.A. \& S.D. Gillespie. (ed.). 2015. Things in motion: object itineraries in anthropological practice. Santa Fe (NM): School for Advanced Research.

Kroesen, J.E.A. \& V.M. Schmidt (ed.). 2009. The altar and its environment 1150-1400. Turnhout: Brepols.

Morris, C.A. 2000. Craft, industry and everyday life: wood and woodworking in Anglo-Scandinavian and medieval York. York: Council for British Archaeology.
Reilly, E. 2012. Fair and foul: analysis of sub-fossil insect remains from Troitsky XI-XIII, Novgorod (1996-2002), in M.A. Brisbane, N.A. Makarov \& E.N. Nosov (ed.) The archaeology of medieval Novgorod in context. 265-82. Oxford: Oxbow. https://doi.org/10.2307/j.ctvh1dqcg.25

TaAvitsainen, J.-P., J. Vilkuna \& H. Forssell. 2007. Suojoki at Keuruu: a mid-14 ${ }^{\text {th }}$ century site of the Wilderness Culture in the light of settlement historical processes in central Finland. Helsinki: Finnish Academy of Science and Letters.

TÅngeberg, P. 2005. Retabel and Altarschreine des 14. Jahrhunderts: Schwedische Altaraustattungen in ihrem europäischen Kontext. Stockholm: Kungliga Vitterhets Historie och Antikvitets Akademien.

TAubert, J. 2015. Polychrome sculpture: meaning, form, conservation. Los Angeles (CA): Getty Conservation Institute.

Vuola, K. 2019. Wood species and the question of origin: reassessing the sculpture production in the Diocese of Turku ( $\AA$ bo) during the $14^{\text {th }}$ century. Baltic Journal of Art History 18: 75-104. https://doi.org/10.12697/BJAH.2019.18.02

Weismantel, M. \& L. MesKell. 2014. Substances: 'following the material' through two prehistoric cases. Journal of Material Culture 19: 233-51. https://doi.org/10.1177/1359183514546803

(C) The Author(s), 2020. Published by Cambridge University Press on behalf of Antiquity Publications Ltd 